\title{
Brexit: An Assessment, Implications, and Strategy for Pakistan
}

\author{
* Aisha Riaz, Lecturer \\ ** Dr. Muhammad Ayyoub, Assistant Professor (Corresponding Author) \\ **** Fouzia Yasmin, Lecturer
}

\begin{abstract}
Currently, Brexit is a reality. How much of an impact will Brexit have on the economy of Pakistan? We address this question by analyzing Pakistan's most recent trade data. Since in the existing European Union, Britain, France, Germany, and Italy are among the major exporting destinations, the economy of Pakistan cannot remain entirely immune to the implications of Brexit. However, our analysis shows that after the Brexit-vote in Britain on 23 June 2016, economic indicators of Pakistan remained stable, and the Brexit pressure on Pakistan's economy has remained relatively muted so far. To maintain the ongoing stable export trends, we suggest that Pakistan needs to modernize its political diplomacy by formulating separate policies for Britain and the post-Brexit EU. Additionally, we propose that, instead of signing a free trade agreement (FTA) with the United Kingdom, Pakistan should bargain for an agreement like the 'Generalized Scheme of Preferences Plus to access the postBrexit UK market.
\end{abstract}

Keywords: Brexit; GSP Plus; Pakistan; Trade Policy; United Kingdom

JEL classification: F13; F14

Introduction

On 23 June 2016, the Britons voted for a sovereign choice to leave the European Union (EU). It was named 'Brexit', a combination of 'Br' from Britain and 'exit' as an 'exit from the EU'. This happened because of a commitment made by Britain's former PM David Cameron in January 2013 to hold a referendum on the UK's EU membership. Although the motivation for this choice was mainly political (such as repatriating powers back from the EU), it has a widespread global economic impact. As described by Gamble (2017), "Brexit offers the possibility both that everything may change and that nothing may change".

As the most heated debate among policymakers of the world centers around how Brexit may re-shape the structure and trends of the global economy and the likely consequences for the European Union, the policy-making institutions of developing economies cannot stand aside. The relevant question for Pakistan is: how much of an impact will Brexit have on Pakistan? What steps can be taken to immune the economy and people of Pakistan from Brexit? The above forms the agenda for this paper.

While one view is that Brexit will not largely impact Pakistan's economy, and is unlikely to alter the international trade structure of Pakistan, another viewpoint is that the economy is not entirely immune to the Brexit-effects either. The supporters of the first notion are forecasting that Brexit will not largely impact Pakistan's economy. They argue that the Brexit pressure on the economy of Pakistan is relatively muted and that the direct impact of Brexit on Pakistan would be far lesser than the picture being portrayed in print and electronic media. For instance, Javed (2016) suggested that Pakistanis should not worry a lot because the global markets comparatively protect Pakistan. This hypothesis is also supported by the argument that the key trading players of Pakistan are non-

\footnotetext{
* Department of Management Sciences, University of Okara, Okara, Pakistan. Email: aisha.riaz1@ outlook.com

** Department of Economics, University of Sahiwal, Sahiwal 57000, Pakistan.

Email: m.ayyoub@uosahiwal.edu.pk

*** Department of Economics, University of Sahiwal, Sahiwal 57000, Pakistan.
} 
European countries (for example, China, Kuwait, Saudi Arabia, UAE, and the USA). ${ }^{1}$ Whereas, only China's weight in Pakistan's international trade offsets the cumulative trade weight of all major European economies. ${ }^{2}$ Therefore, one might expect that Brexit is unlikely to alter the direction of the economy significantly.

The alternative to the above hypothesis considers that the economy of Pakistan is not entirely immune to the Brexit-effects either. The situation demands an in-depth analysis and considerable attention of policymakers. The supporters of this viewpoint argue that Kuwait, Saudi Arabia, and UAE are among the major trading partners that have helped worsen Pakistan's balance of trade (BOT). To minimize the trade deficit, Pakistan is required to leverage on bigger export destinations, foreign aids, and grants providing countries and sources of foreign remittances.

Motivated by the discussion above, there is a thirst to evaluate the potential consequences of the Brexit on the economy and people of Pakistan. In this study, we have tried to fill this gap by descriptively analyzing all possible implications. How much of an impact will the Brexit have on the economy of Pakistan? What can be the possible suggestions to immune the economy and people of Pakistan from the Brexit? In Pakistan, to the best of our knowledge, we are the first to throw light on these questions. The net contribution of our study is that it examines a new dimension of the postBrexit trade policy of Pakistan by focusing purely on economic arguments. Also, by analyzing possible conflicts with the post-Brexit EU, it throws light upon examining how post-Brexit EU may impact on the trade policy of Pakistan. The scope of this study is vast enough to provide guidelines to the exporters and trade policy analysts of Pakistan.

The remainder of this article is organized as follows. In the next section, we briefly review the existing EU set-up and highlight the relevant literature on Brexit-effects, followed by the section that presents the foreign-trade structure of Pakistan, followed by the section that highlights the potential significance of the UK-PAK relationship for Pakistan. The analysis of the impact of Brexit on Pakistan is performed in the second to last section. The last part concludes the story.

\section{Background and Relevant Literature}

Before examining Pakistan specifically, let us introduce the background of the EU and a brief overview of existing literature on Brexit-effects for the interest of the reader. As the European Union (known as the EU) is not just a single market of 28 European countries that assist member economies, it has been a great political project. The EU has created major institutions embodied with supreme judicial and executive authority over the major European countries. The EU does legislation by passing new laws that are broadly valid throughout the EU states. The most suitable examples are the European Court of Justice and the European Parliament.

From an economic viewpoint, all member states are considered as an integrated economy. The exchange of commodities and capital is restriction-free. Border restrictions are more relaxed and people can move freely. However, the movement of labor is under certain checks. With the implementation of a unified currency regime within the EU, the Euro became a symbol of a single economy. The establishment of the Euro currency opened trade and commerce by expanding the EU industry through the sharing of the fruit of science and technology. Less border controls amongst member countries enabled the exchange of skilled human resources to the benefit of all of Europe. As an example, when the financial crisis of 2008 hit the global economy, the Lisbon Treaty was endorsed by the EU member states and formally implemented in 2009. This treaty guarantees the EU states with new and comparatively more efficient institutions and working environment.

Hunt and Wheeler (2017) reported that for the United Kingdom to formally leave the European Union, it has to invoke an article (i.e., Article 50 of the Lisbon Treaty). The UK MPs have already backed the Article 50 Bill on 1 February 2017. This article has been working only since 2009 and has not been tried so far. Therefore, nobody knows how the Brexit process will work. ${ }^{3}$ It is widely based on the particular type of deal the UK will agree with the EU, as a result of negotiations after Article 50 has been triggered formally by the UK Parliament. If both parties agree to keep the UK

\footnotetext{
${ }^{1}$ Table 1 and Figure 1 display full detail.

${ }^{2}$ According to DOTS, the cumulative trade weight of 10 major European economies, in Pakistan's foreign trade, is about $12.5 \%$, which is outweighed by only the Chinese trade weight of $16.1 \%$.

${ }^{3}$ Geoghegan (2017) noted that even on the eve of the triggering of Article 50, people do not have any clearer detail of how the UK will leave the EU.
} 
within the European single market, it will surely retain the rights to free mobility of people and labor class. According to these rights, the European labor will be allowed to work freely either in the UK or in the post-Brexit EU. Otherwise, following the slogans of the 'Leave' campaign, if the UK will opt to impose work permit restrictions, then other EU states could respond in the same manner.

Malakat (2016) reported that Brexit would have widespread repercussions around the globe, which are hard to assess in terms of scope, duration, and size. The initial impact of the 'Leave' result had been observed globally because of the prevailing uncertainty as part of the British postreferendum reality. The Brexit vote has advanced political, economic, and social changes globally. ${ }^{4}$ Economic and trade-based integration have also been highly questioned. Hence, we can conclude that Brexit owes a huge possibility of implications to lead to a set of renewed political and socio-economic relationships of world nations.

The post-Brexit UK's place in the global trade plan will bring additional shifts in the trade corridors. The political sphere will not also remain unaffected. For instance, there is already a narrative prevailing for the greater British engagement with Iran in the post-Brexit world. Since Brexit is now a reality, for purely economic purposes, almost all nations of the world have started thinking about the post-Brexit world, and to formulate their post-Brexit strategy. For instance, Pisani-Ferry et al. (2016) proposed a new strategy of cooperation for a long-lasting partnership between the UK and the rest of Europe. In their opinion, the UK wants to have some control over the movement of labor mobility. This continental partnership would be consisting of participating in the mobility of commodities and capital, and some arrangement of a temporary movement of labor. Additionally, they proposed a new set-up of inter-governmental decision-making and implementation of standard rules to protect the homogeneity of the deeply integrated market. They are hopeful that, in the long run, their proposal could work as a great agenda to deal with Turkey, Ukraine, and other countries.

Roy and Somesh (2016) presented a post-Brexit Indian proposal for the EU and UK. India has recently been negotiating with the EU for a free trade agreement (FTA). However, after the Brexit, bilateral trade costs between the UK and EU will tend to increase in terms of newly applicable tariff and non-tariff barriers. As a result, India will have to face a considerable impact on her trade flows with the UK and the EU. They attempted to examine the impact of trade liberalization on the mutual trade between India and the EU. Moreover, they also analyzed the comparative welfare effects of the pre-vote situation and post-Brexit arrangements. They suggested that post-Brexit trade deal would be less beneficial for India. Their results reveal that India and the EU gain more in the preBrexit set of arrangements.

Most recently, Nicolaides and Roy (2017) addressed the claims by Brexit-supporters in terms of the UK's trade arrangements with the EU after the negotiations are over. They reviewed the potential impact and significance of the UK-EU trade links before and after the Brexit and potential costs the UK will bear in exchange for 'taking back control' of its trade policy. They concluded that the claims by Brexit-supporters are based on logically inconsistent arguments, and after the UK enters into more post-Brexit bilateral agreements, the attractiveness of the UK market will progressively decline.

\section{Foreign Trade Structure of Pakistan}

According to IMF's Direction of Trade Statistics (DOTS) database, China, UAE, Saudi Arabia, USA, Afghanistan, Kuwait, Malaysia, Iran, Germany, Japan, India, United Kingdom, Italy, Singapore, and France are major trading partners of Pakistan (w.r.t., trade weights). Pakistan Economic Survey (2016) reported that Pakistan's annual import and export volumes across the world stand around $\$ 50$ billion and $\$ 23$ billion, respectively. In the present EU arrangement, Pakistan's largest trading partners are Germany, UK, Italy, and France. Whereas, Germany and the UK are Pakistan's largest export destinations.

\footnotetext{
${ }^{4}$ Meagher (2017) considers Brexit as the most significant event for the UK since the end of the WWII.
} 


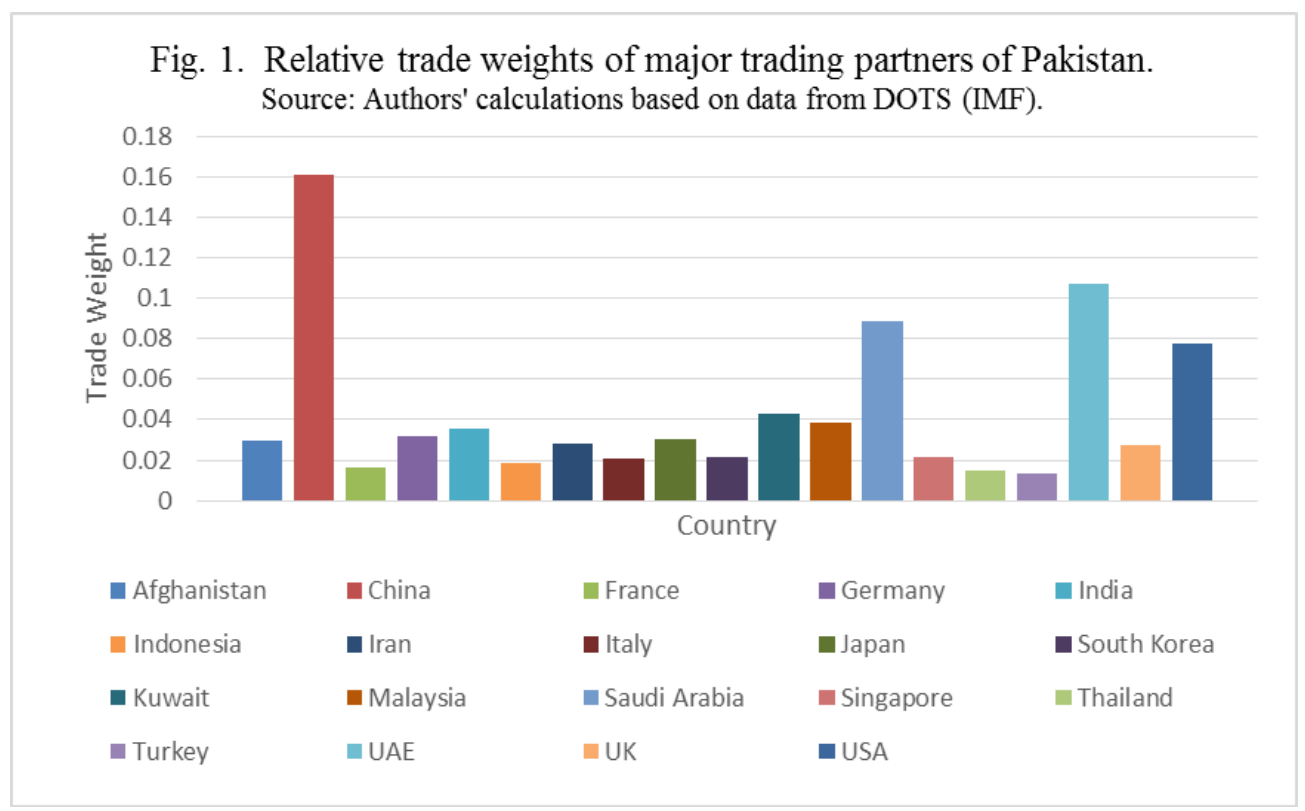

Table 1

Relative trade weight of all trading partners of Pakistan.

\begin{tabular}{llllll}
\hline$(1)$ & $(2)$ & $(3)$ & $(4)$ & $(5)$ & $(6)$ \\
Country & Weight & Country & Weight & Country & Weight \\
\hline Afghanistan & 0.030 & Indonesia & 0.018 & Russia & 0.006 \\
Argentina & 0.002 & Iran & 0.028 & Saudi Arabia & 0.088 \\
Australia & 0.011 & Italy & 0.021 & Singapore & 0.022 \\
Austria & 0.002 & Japan & 0.030 & South Africa & 0.007 \\
Bahrain & 0.004 & Kenya & 0.006 & Spain & 0.009 \\
Bangladesh & 0.008 & South Korea & 0.021 & Sri Lanka & 0.005 \\
Belgium & 0.012 & Kuwait & 0.043 & Sweden & 0.006 \\
Brazil & 0.005 & Malaysia & 0.038 & Switzerland & 0.006 \\
Canada & 0.012 & Mexico & 0.003 & Taiwan & 0.010 \\
China & 0.161 & Morocco & 0.005 & Thailand & 0.015 \\
Egypt & 0.004 & Netherlands & 0.013 & Turkey & 0.013 \\
Finland & 0.002 & New Zealand & 0.002 & UAE & 0.107 \\
France & 0.017 & Norway & 0.001 & UK & 0.027 \\
Germany & 0.032 & Oman & 0.009 & Ukraine & 0.003 \\
Hong Kong & 0.009 & Philippines & 0.002 & USA & 0.077 \\
India & 0.035 & Qatar & 0.005 & Vietnam & 0.005 \\
\hline S & & & &
\end{tabular}

Sum $(2+4+6)=1$

Table 1 reflects the diversity and foreign-trade structure of Pakistan. The column (2), (4), and (6) present relative trade weights of 48 major trading partners that account for more than $90 \%$ of the foreign trade of Pakistan. The sum of all trade weights equals unity. Source: Authors' calculations based on data from IMF's DOTS database.

Pakistani exports to the UK and the EU are mainly comprised of textile, clothing, and leather products. According to the Pakistan Economic Survey (2016), around 21.2\% of Pakistan's total exports are being sent to the existing EU market. Pakistan's exports to the EU are helped by the 'Generalized Scheme of Preferences Plus (GSP Plus) status, which allows Pakistan to export its commodities at zero or reduced duty to the EU market. Paracha (2016) noted that the UK helped Pakistan in getting EU trade privileges. Consequently, Pakistan's exports to the EU countries reached a milestone of $\$ 7$ billion per year. After January 2014, Pakistani exports to the UK, as facilitated by the duty-free GSP Plus arrangement to the EU, increase by $40 \%$.

As a result of GSP Plus from the EU, net Pakistani exports increased from $\$ 6.21$ billion (2013) to $\$ 7.54$ billion (2014). Pakistan's bilateral trade with the GSP Plus countries has recently reached a $\$ 10.5$ billion figure. Pakistan's share is around $\$ 4.40$ billion and remaining belongs to the 
EU countries. Table 2 shows that, according to the UN Comrade Database, the UK remained the top destination for Pakistani exports during 2012-2015. Whereas, Germany is the $2^{\text {nd }}$ place, where most of our exports land in the EU.

Table 2

Exports of Pakistan to major European trading partners during 2012-2015.

\begin{tabular}{llllll}
\hline Exports & EU-28 & France & Germany & Italy & UK \\
\hline 2012 & 5278.2 & 713.6 & 1269.3 & 553.3 & 1307.3 \\
2013 & 6015.2 & 806.8 & 1415.9 & 632.9 & 1450.6 \\
2014 & 7317.3 & 923.2 & 1696.3 & 739.9 & 1788.4 \\
2015 & 6734.0 & 819.7 & 1599.3 & 641.3 & 1675.3 \\
\hline Average & 6336.18 & 815.83 & 1495.2 & 641.85 & 1555.4 \\
\hline
\end{tabular}

Authors' calculation based on data from UN Comrade Database, expressed in millions USD.

\section{Significance of UK-PAK Relationship for Pakistan \\ Mutual Political Interests}

Due to Britain's historical attachment, Pakistan grasps a great strategic potential. Pakistan is one of the oldest allies of the UK to enhance the strategic influence of the UK in the South Asian region. Since the policymakers in the UK have developed a new diplomatic strategy to win back influence in South Asia, Britain always seeks cooperation from Pakistan. Pakistan also helped the UK to reverse the trend, so that strategically involved countries in South Asia may rely again on Britain. British officials view that bilateral relations with Pakistan are aimed to enhance the prosperity of both countries. Pakistan has become more important for the UK as China has set her sights widely in Pakistan through the much-appreciated and well-referenced "China-Pakistan Economic Corridor (CPEC)."

On the other hand, the UK is one of the greatest politically dependable entities for Pakistan. The UK has always been performing the role of 'mediator' for Pakistan regarding its relationships with the EU, India, and the USA. For instance, for the sake of diplomacy at EU institutions, Pakistan had traditionally been dependent on British support. Pakistan has also sought for the British mediation role to settle the Kashmir dispute with India.

\section{Social Importance}

According to the British Department of International Development (DFID), Pakistan receives more British aid compared to any other country in the world. The DfID estimated that Pakistan received $£ 350$ million in 2015. The UK-Policy for Pakistan is not only focused on security matters but also on the economic and cultural development of Pakistan. Thus, in 2015, the Foreign \& Commonwealth Office (FCO) of the UK presented a new education plan for Pakistan. Accordingly, the FCO helped enroll 4 million new children in schools: train 90,000 schoolteachers annually, and construct more than 20,000 classrooms for students.

The UK is also of vital importance for Pakistanis in the UK. Britain is the third-largest home (after Saudi Arabia and UAE) for Pakistani workers in the world. Around 1.7 million persons of Pakistani origin live in the UK, which is even larger than the combined population of Pakistani diaspora in the rest of the EU countries. Pakistanis in the UK are relatively prosperous and have strong economic connections in Pakistan. They are a significant base of foreign direct investment inflows into Pakistan.

\section{Economic Connections}

The bilateral trade and investment relationship between Pakistan and the UK holds great significance. After China and the US, UK is the third-largest importer of Pakistani goods. Pakistan Economic Survey (2016) reports that the trade volume between Pakistan and the EU stands at $\$ 2$ billion. Of which, Pakistan's exports to the UK reached the figure of $\$ 1.5$ billion. Since Pakistan is trying to enhance its export volume, the UK is one of the leading destinations. Zaheer and Alam (2016) reported that Pakistani exports to the UK are valued at around $\$ 1.68$ billion per annum. According to the UN Comrade Database, the net volume of trade between Pakistan and the UK reached $\$ 2.47$ billion in 2015. The balance of trade (BOT) stood in favor of Pakistan because Pakistani exports to the UK stood at $\$ 1.68$ billion while its imports remained at $\$ 0.79$ billion. Moreover, Pakistani 
nationals send more than $\$ 2$ billion remittances annually, and the UK also invests around $\$ 1$ billion in various projects in Pakistan.

Besides, more than 100 British companies operate their businesses in Pakistan ("UK-Pak trade", 2016). As a result of a $2016 \mathrm{MoU}$ between the British Business Centre and the Karachi Chambers of Commerce and Industry, the British government has established its business centers in Karachi and Lahore. ${ }^{5}$ The goals of this set up are to contribute towards bilateral trade and investment; to help British and Pakistani businesses develop closer links with each other; to offer firsthand opportunities to British firms and investors in Pakistan. The opening of two British Business Centers has significantly enhanced the support available to UK and Pakistani enterprises. This support includes market research, business opportunity promotion, event management, networking opportunities, professionally adapted, and sector-specific services.

\section{Potential Consequences of Brexit for Pakistan and Possible Remedies}

Until now, both countries have enjoyed a pleasant and long-standing mutual relationship. However, as Article 50 of the Lisbon Treaty has been triggered formally by the UK Parliament, there are many concerns over trade negotiations. The policymakers in Pakistan are looking forward to the outcome of a two years protracted negotiations between the UK and the EU, and the type of agreement the UK will be able to achieve from the EU. Secondly, what will be the UK-Policy for the future of UK-PAK political and economic relations? There are nice hopes that Pakistan will also be able to agree on an encouraging trade agreement with the post-Brexit UK. However, during this changeover period of two years, both Pakistan's government and exporters will face challenges.

\section{Political Scenario}

Brexit might not have profound effects on UK-PAK political relations, but there may be substantial import-based consequences for Pakistan at the multilateral environment in post-Brexit EU. After the Brexit, Pakistani diplomacy would be challenged to proactively befriend non-British important member states where Pakistani diaspora has minor electoral influence over MPs. Besides, IMF predicts that among the Commonwealth countries, Pakistan will be outweighed by India due to India's larger economic significance and broader market size (Chabe, 2016). Therefore, the fear is that Pakistan might not feature high on the UK's priority list to commit its negotiating resources during the coming years. So, a new lobbying effort would be required to secure such unilateral concessions from post-Brexit UK. In this scenario, Pakistan is required to modernize its political diplomacy to convince other influential EU countries, for discovering promising political opportunities and economic markets to impact the decision-making process in the big EU countries (e.g., Germany, France, and Italy). Moreover, Pakistani diplomats will also be required to strategizing separate policies towards Britain and the EU.

\section{Economic Implications of Brexit for Pakistan}

Brexit is Unlikely to Impact Pakistan. Why?

As world markets undergo an uncertain situation of the negotiations between the UK and the EU, some analysts in Pakistan are forecasting that the Brexit will not largely impact Pakistan's economy. For instance, Javed (2016) suggested that Pakistanis should not worry a lot because the global markets comparatively protect Pakistan. He added that as exports constitute only $7 \%$ of Pakistan's GDP, Pakistan rarely relies on its exports. Therefore, the Brexit pressure on the economy of Pakistan is relatively muted so far. We present (Figure 1) that the underlying viewpoint is supported by the argument that key trading players of Pakistan are non-European countries (i.e., China, Kuwait, Saudi Arabia, UAE, and USA). Table 1 indicates that the cumulative trading weight of 10 major EU countries (i.e., Austria, Finland, France, Germany, Italy, Netherlands, Norway, Spain, Sweden, and the UK) in international trade of Pakistan is about $12.5 \%$, which is even lesser than only the Chinese trading weight of $16.1 \%$. Therefore, one might expect that Brexit is unlikely to alter the direction of the economy significantly. A few assurances also strengthen this viewpoint. For instance, the Deputy High Commissioner of the UK to Pakistan, Ms Belinda Lewis, has recently assured that post-Brexit political changes would never impact on UK-PAK trade relations and the signing of an FTA with Pakistan. However, since the UK is withdrawing from the EU, Pakistan would not be able to enjoy GSP Plus status anymore in the UK. Also, the Commerce Secretary of Pakistan has recently

\footnotetext{
${ }^{5}$ http://www.bbcpk.org/
} 
quoted that, in the backdrop of Brexit, Pakistan would be provided with a package like the GSP Plus by the UK. He stated that: "We are happy that the UK authorities have responded to us very positively; we have been assured that Pakistan would be given a handsome package for trade, in line with the GSP Plus as available for Pakistan in the EU markets".

The most recent data on the monthly exports of Pakistan also supports this viewpoint. Figure 2 and Table 3 present statistics on Pakistani exports to the UK, Germany, France, and Italy, before and after the '23 June 2016 referendum' in Britain. We can observe a stable trend in exports even after the Brexit vote. Even the highest figures during reported months, January-September 2016, can be found after the Brexit-vote. As our exports remained unaffected by Britain's exit vote, we can derive that foreign trade of Pakistan is not vulnerable to changes in the EU set-up. However, another viewpoint is that the steady trend in exports, after June 2016, is due to ongoing GSP Plus status to the UK and the EU. This situation demands considerable attention of policymakers. Efforts should be made to maintain the ongoing stable export trends to the continent of Europe and to keep the ongoing GSP Plus status.

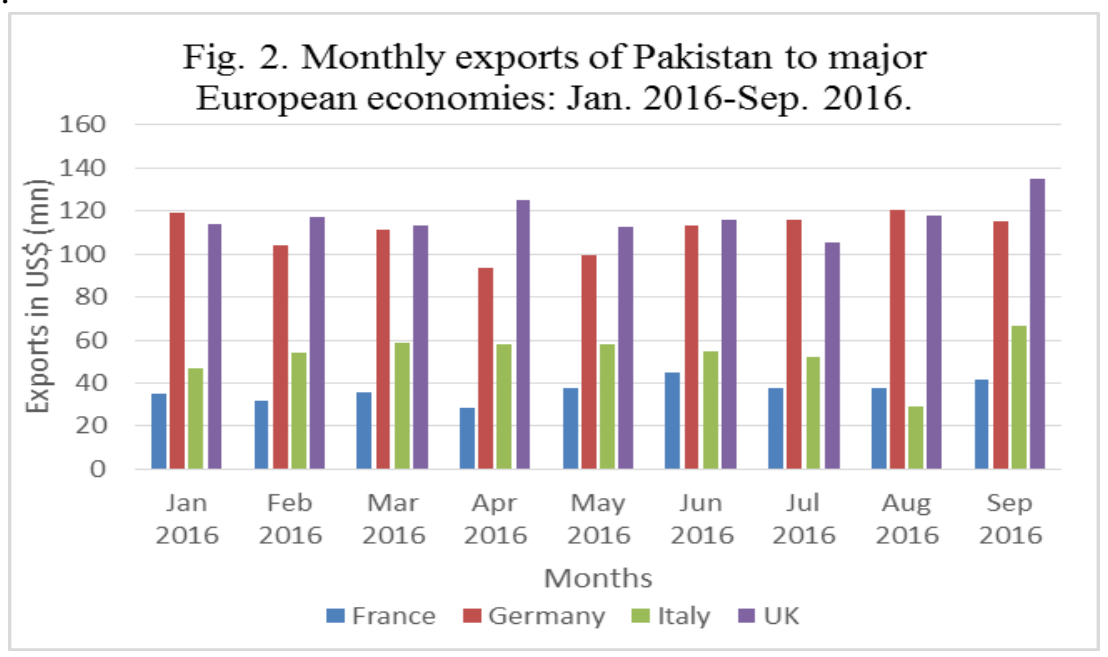

Table 3

Pakistan's monthly exports to major EU partners.

\begin{tabular}{lllll}
\hline (1) & $(2)$ & $(3)$ & $(4)$ & $(5)$ \\
Month & France & Germany & Italy & UK \\
\hline Jan 2016 & 35.27 & 118.92 & 46.98 & 114.18 \\
Feb 2016 & 31.73 & 104.22 & 53.95 & 116.99 \\
Mar 2016 & 35.98 & 111.21 & 58.57 & 113.31 \\
Apr 2016 & 28.33 & 93.84 & 58.2 & 125.15 \\
May 2016 & 38 & 99.55 & 58.01 & 112.28 \\
Jun 2016 & 44.93 & 113.33 & 54.8 & 116.01 \\
Jul 2016 & 37.52 & 115.62 & 51.87 & 105.67 \\
Aug 2016 & 37.6 & 120.69 & 28.89 & 117.7 \\
Sep 2016 & 41.66 & 115.44 & 66.45 & 135.26 \\
\hline
\end{tabular}

Source: DOTS (IMF) expressed in millions USD.

Pakistan is Not Immune to the Brexit Effects. Why?

Let us analyze the alternative view that the economy of Pakistan is not entirely immune to the Brexit effects either. Based on the following arguments, government and political economists of Pakistan cannot afford to lethargically sleep-walk into the challenges Brexit is going to generate.

Firstly, we argue that Kuwait, Saudi Arabia, and UAE are among the major trading partners that have helped worsen Pakistan's balance of trade (BOT). To minimize the trade deficit, Pakistan is required to leverage on bigger export destinations, foreign aids, and grants providing countries and sources of foreign remittances. Secondly, following the Brexit referendum news, despite repeated assurances from the Ministry of Commerce of Pakistan that Brexit will not affect Pakistan's exports to 
the EU, the stock market of Pakistan fell by over 1400 points. This happened because of the panic in the auto and textile sectors.

Thirdly, with a quarter of Pakistan's total exports' destination in the existing EU countries, the UK has been Pakistan's largest trading partner in the 28-nation bloc. Brexit can cause a significant decrease in the trade volume, between Pakistan and the current EU. The Ministry of Finance of Pakistan reported that, after the Brexit, exports of Pakistan could get hurt because the UK has a relative power of her presence over the entire EU. Pakistani exporters are anxious to know if Pakistan will receive the same GSP Plus status in post-Brexit UK and EU. The trade agreement with the postBrexit EU has significant implications.

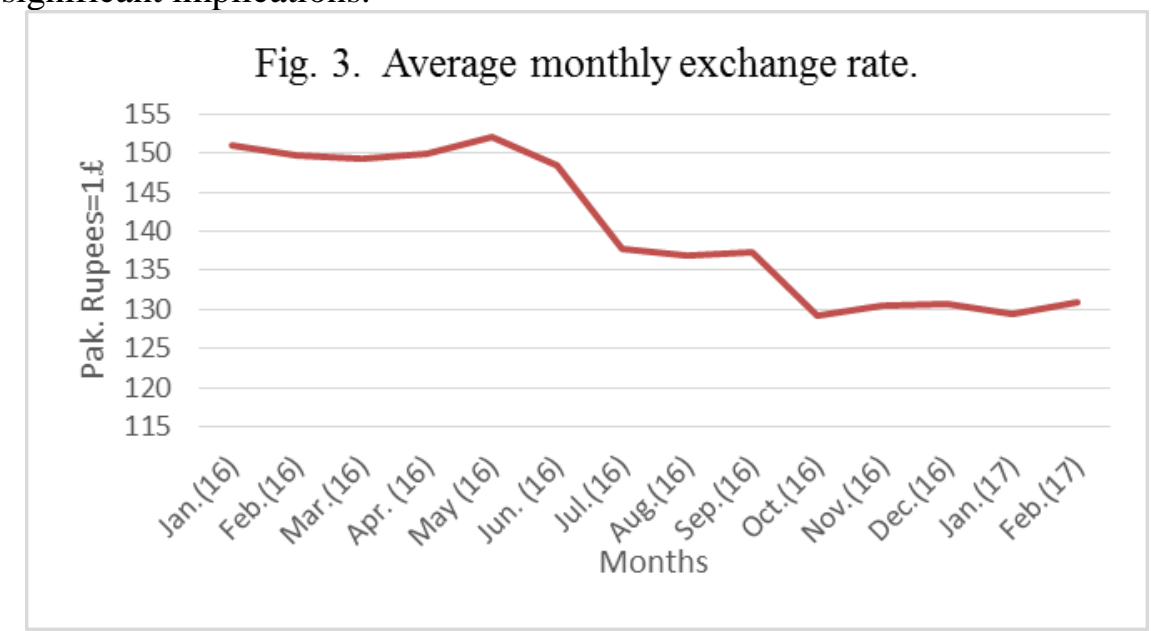

Fourthly, considering foreign aid, the UK is one of Pakistan's principal donors and has reliably supported in building Pakistan's social and economic sectors. Now, with the uncertainty present in the UK economy, there is apprehension that bilateral aid and grants would decrease. Without considering fluctuations in the value of the Pound Sterling, welfare grants and security aid have a momentous qualitative value for Pakistan. Any cut in such grants will not be an appreciated sign. In addition to this, while the rest of the EU member states contribute only $3 \%$ of entire foreign remittances, the UK alone provides almost $20 \%$ of total remittances in Pakistan. Also, better health of the European economies and their currencies (e.g., GBP and Euro) are of vital importance to Pakistan. Any possible depreciation in the value of these currencies will make Pakistani exports less attractive, resulting in a decrease in their demand.

Figure 3 and Table 4 report the exchange rate, on the average monthly basis, the declining trend of the exchange rate, between the British Pound and the Pakistani Rupee. The trend shows that GBP depreciated immediately after the vote for Brexit in June 2016. The same also happened with the Euro. Whereas, safe havens like gold and the Japanese yen attracted the attention of investors and the public. As the Pakistani automotive sector is a regular importer of parts from Japan, an appreciation of YEN may have adverse effects.

Finally, according to Chabe (2016), IMF officials believe that by 2019, Commonwealth economies will overtake the EU countries in the world's economic output. Once the Brexit formally happens, the UK will have to negotiate market access afresh with all world nations, and it is widely believed that post-Brexit UK will desire to improve its economic relationships with Commonwealth partners. Pakistan would be required to put a focus on business diplomacy separately with Britain and the post-Brexit-EU. Otherwise, Pakistani exports to the UK could drop considerably. In this regard, Pakistani policymakers should follow the 'Trade and Investment Roadmap 1994', which was signed by British PM John Major and late PM Benazir Bhutto. This road map, built on the Bilateral Investment Treaty, had been aimed at raising the bilateral trade to $£ 2.5$ billion annually.

Table 4

Average monthly exchange rate in Pak. Rupees: Comparison of GBP, EURO, and YEN

\begin{tabular}{llll}
\hline$(1)$ & $(2)$ & $(3)$ & $(4)$ \\
Month & $£$ & $€$ & $¥$ \\
\hline Jan 2016 & 151.08 & 113.91 & 0.89
\end{tabular}




$\begin{array}{llll}\text { Feb 2016 } & 149.63 & 116.16 & 0.91 \\ \text { Mar 2016 } & 149.33 & 116.61 & 0.93 \\ \text { Apr 2016 } & 149.84 & 118.81 & 0.96 \\ \text { May 2016 } & 152.07 & 118.32 & 0.96 \\ \text { Jun 2016 } & 148.36 & 117.58 & 0.99 \\ \text { Jul 2016 } & 137.72 & 115.91 & 1.01 \\ \text { Aug 2016 } & 136.99 & 117.25 & 1.03 \\ \text { Sep 2016 } & 137.34 & 117.13 & 1.02 \\ \text { Oct 2016 } & 129.17 & 115.37 & 1.01 \\ \text { Nov 2016 } & 130.45 & 112.96 & 0.97 \\ \text { Dec 2016 } & 130.70 & 110.37 & 0.90 \\ \text { Jan 2017 } & 129.32 & 111.33 & 0.91 \\ \text { Feb 2017 } & 130.84 & 111.87 & 0.93\end{array}$

Source: www.X-rates.com

\section{Key Suggestions for Pakistan's Post-Brexit Strategy}

Due to the significance of the UK on Pakistan's political economy and foreign trade, Brexit demands proactive policy action to identify the nature of post-Brexit challenges for Pakistan and appropriate remedies. While one viewpoint is that exports of Pakistan to the EU and UK are not vulnerable to Brexit, and is unlikely to alter the international trade structure and direction of the economy of Pakistan, another viewpoint is that the steady trend in exports, after June 2016, is due to ongoing GSP Plus status to the UK and the EU. This situation demands considerable attention from policymakers. Efforts should be made to maintain the ongoing stable export trends to the continent of Europe and to keep the ongoing GSP Plus status. In doing so, we can prioritize the key suggestions that might be of help for Pakistan's strategy as follows:

Firstly, Pakistan should modernize its political diplomacy immediately, to convince major powers (e.g., Germany, France, and Italy) to acquire a reasonable market share in the post-Brexit EU. Diplomats should strategize separate policies for Britain and the post-Brexit EU to have a beneficial influence on the decision-making process. Assigning an FTA with the UK means Pakistan would also be required to grant the same concessions, instead of signing an FTA, Pakistan should bargain for a new GSP Plus-type agreement to access the UK market.

Secondly, once the Brexit formally happens, UK will have to negotiate market access afresh with all world nations. It is widely believed that post-Brexit UK will be more inclined to improve its political and economic ties with Commonwealth partners. Since Pakistan might not feature high on the UK's priority list, a new lobbying energy would be needed to protect such unilateral benefits from post-Brexit UK. Finally, Pakistan should actively try to implement and follow the so-called 'Trade and Investment Roadmap,' which was signed by British and Pakistani prime ministers in 1994.

\section{Concluding Remarks}

The Brexit strategy demands a proactive policy to identify the nature of post-Brexit challenges for our economy. There is also a thirst to develop a dynamic response mechanism in the aftermath of global Brexit effects. Due to the significance of the UK on Pakistan's political economy and foreign trade, the Brexit strategy has many weighty implications. Most recent data show that exports of Pakistan to the EU and the UK are not vulnerable to Britain's exit vote. However, this steady trend in exports is because of the ongoing GSP Plus status to the UK and the EU. Therefore, we expect that the Brexit is unlikely to alter the international trade structure and direction of the economy of Pakistan if we can keep this GSP Plus status. However, considerable attention of commerce policymakers is required to maintain the ongoing stable export trends to the continent of Europe. We would only be able to keep the ongoing GSP Plus status for our exports to the UK and post-Brexit EU if Pakistani diplomats can strategize Pakistan's separate policy towards Britain and the EU.

\section{References}

Business Recorder Report. (2016, July 23). UK-Pak trade: Political change after Brexit poll would never affect ties. Business Recorder. Retrieved from http://epaper. brecorder.com/2016/07/23/5-page/778867-news.html 
Chabe, T. (2016, March 2014). Brexit will allow Britain to embrace the commonwealth. The Telegraph. Retrieved from http://www.telegraph.co.uk/news/newstopics/eureferendum/ 12193101/Brexit-will-allow- Britain-to-embrace-the-ommonwealth.html

Gamble, A. (2017). British politics after Brexit. Political Insight, 8(1), 4-6.

Geoghegan, P. (2017). Editorial. Political Insight, 8(1), 3-3.

Government of Pakistan. Pakistan Economic Survey (various issues). Ministry of Finance, Islamabad (Pakistan). Retrieved from http://www.finance.gov.pk/survey_1415.html

Government of the United Kingdom. Department for International Development (DfID). Retrieved from https://www.gov.uk/government/organisations/department-for-international-development

Government of the United Kingdom. Foreign \& Commonwealth Office (FCO). Retrieved from https://www.gov.uk/government/organisations/foreign-commonwealth-office

Government of the United Kingdom. New Agreement Promotes Trade between the UK and Pakistan. Retrieved from https://www.gov.uk/government/world-location-news/new-agreementpromotes-trade-between-UK-and-pakistan

Government of the United Kingdom. Pakistan UK Trade and Investment Roadmap. Retrieved from https://www.gov.uk/government/news/pakistan-uk-trade-and-investment-roadmap

Hunt, A., \& Wheeler, B. (2017, February 15). Brexit: All you need to know about the UK leaving the EU. BBC News. Retrieved from http://www.bbc.com/news/uk-politics- 32810887

International Monetary Fund. Direction of Trade Statistics (DOTS). IMF e-library. http://data. imf.org/

Javed, U. (2016, July 5). How will Brexit impact Pakistan? The Diplomat. Retrieved from http://thediplomat.com/2016/07/how-will-brexit-impact-pakistan/

Malakat, A. (2016, July 4). What does Brexit mean for trade? World Economic Forum Blog. Retrieved from https://www.weforum.org/agenda/2016/07/trade-finance-and-the-brexit/

Meagher, K. (2017) Could Brexit Break up the UK? Political Insight, 8(1), 16-19.

News and Views. (2016). UK assures Pakistan similar trade package like GSP Plus status (Brief article). Pakistan Textile Journal 65(10), 1-4. URL: http://www.ptj.com.pk/Web-2016/102016/News-and-Views-Index.html

Nicolaides, P., \& Roy, T. (2017). Brexit and trade: Between facts and irrelevance. Intereconomics, 52(2), 100-106.

Paracha, S. (2016, June 27). Brexit may hit trade between Pakistan, Britain. The Daily Times. Retrieved from http://dailytimes.com.pk/islamabad/27-Jun-16/brexit-may-hit-trade-betweenPakistan-britain

Pisani-Ferry, J., N. Röttgen, Sapir, A., Tucker, P. \& Wolff, P. (2016). Europe after Brexit: A Proposal for continental partnership. Bruegel External Publication, Brussels.

Roy, A., \& Mathur, S. K. (2016). Brexit and India-EU free trade agreement. Journal of Economic Integration, 31(4), 740-773.

UK Politics. (2016, October 2). Brexit: Theresa May to trigger Article 50 by the end of March. $B B C$ News. Retrieved from http://www.bbc.com/news/uk-politics-37532364

United Nations. UN Comtrade Database. Retrieved from https://comtrade.un.org/data/.

Zaheer, F., \& Alam, K. (2016, June 24). Post-Brexit: What it means for the Pakistani economy. The Express Tribune. Retrieved from http://tribune.com.pk/story/1129662/post-brexit -means-

Pakistani-economy/ 